\title{
Significance of the occurrence of chemoautotrophic bacterial endosymbionts in lucinid clams from Bermuda
}

\author{
Michael Schweimanns ${ }^{1} \&$ Horst Felbeck $^{2}$ \\ ${ }^{1}$ Zoologisches Institut der Universität Kiel, Olshausenstr. 40, D-2300 Kiel, Federal Republic of Germany \\ ${ }^{2}$ University of California, San Diego, Scripps Institution of Oceanography, A-002, La Jolla, California 92093, USA
}

\begin{abstract}
Five species of lucinid clams from Bermuda (Codakia costata, Ctena orbiculata, Parvilucina multilineata, Lucina radians, Anodontia philippiana) had ribulose-1,5-bisphosphate carboxylase activity in the gills. Presence of this enzyme of the Calvin-Benson cycle along with dark coloration of gills and morphologically simplified digestive tract strongly suggests presence of chemoautotrophic bacteria living symbiotically with the clams. Natural history is described for these 5 lucinids and several others not studied biochemically. All inhabit reduced sediments rich in organic matter, where hydrogen sulfide is detectable. Results, along with previously published studies, indicate that most clams of the family Lucinidae live symbiotically with chemoautotrophic bacteria in their gills and inhabit sulfide-rich environments.
\end{abstract}

\section{INTRODUCTION}

Since the original discovery of a symbiosis between invertebrates and intracellular chemoautotrophic bacteria in animals from hydrothermal vents (Cavanaugh et al. 1981, Felbeck 1981), this type of symbiosis has been discovered in molluscs (Cavanaugh 1983, Felbeck et al. 1983), pogonophorans (Southward et al. 1981, Southward 1982), and annelids (Giere 1981). A relatively large number of bivalves have been determined by optical and enzymatic methods to contain symbiotic bacteria inside the gill cells. Among these are phylogenetically diverse molluscs including representatives of the protobranchs, Solemya reidi (Felbeck 1983) and S. velum (Cavanaugh 1983), and diverse eulamellibranchs (see Felbeck et al. 1983 for review). So far, all eulamellibranchs known to contain endosymbiotic bacteria are predominantly of the family Lucinidae and, to a lesser extent, of the family Vesicomyidae. Typically, clams with symbionts lack a digestive tract (S. reidi: Reid 1980), or have it greatly reduced ( $S$. velum: Cavanaugh 1983). The symbionts may provide the host bivalves with reduced organic matter, facilitate their digestion or synthesize vitamins necessary for the host (Felbeck et al. 1983). Energy the bacteria need for these tasks is derived mainly from oxidation of sulfide from the environment. This sulfide can originate either from geothermal sources as at the hydrothermal vents or from decaying organic matter as, for example, in the habitat of the clam $S$. reidi, which lives close to sewage outfalls (Felbeck 1983) or near pulp mills (Reid 1980). Similarly, sulfide is produced by decaying seagrass leaves in the habitats of $S$. velum (Cavanaugh 1983) and Lucina floridana (Fisher \& Hand 1984).

In this study we searched for more mollusc species with autotrophic symbiotic bacteria. The survey was conducted in Bermuda in similar habitats to those described for other symbiont-containing bivalves, primarily members of the family Lucinidae. We also addressed the question whether the presence of symbiotic bacteria is characteristic for a given genus or whether it may be an adaptation of individual species or even individual animals.

\section{MATERIAL AND METHODS}

Most ecological studies were conducted during 2 stays on Bermuda, in 1978 and 1980 to 1981. Species for enzyme analysis were collected in Bermuda in July 1984. Specimens were identified using Abbott (1974) 
and Britton (1972). The most common clams Codakia orbicularis, C. costata, Ctena orbiculata, and Parvilucina multilineata were sampled quantitatively by SCUBA diving using an air-suction sampler manually controlled by the diver (frame size of sampled area was $400 \mathrm{~cm}^{2}$; mesh size $500 \mu \mathrm{m}$ ). Collection site for these animals was the inshore lagoon, Harrington Sound, south of Trunk Island where 6 or 7 samples were taken from each of 3 stations ( $3 \mathrm{~m}, 9 \mathrm{~m}$, and $13 \mathrm{~m}$ depth) at monthly intervals. In 1978 samples from 2 transects, from shallow water down into the basin, were used for estimates of animal distribution. Sediments were taken and analyzed for grain size as described by Neumann (1965).

The redox potential discontinuity layer (RPD-layer) was identified by the sulfide dependent change of color in carbonate sediments as described by Adshead (1964).

Since the other 2 species collected, Anodontia philippiana and Lucina radians, are uncommon or rare on Bermuda a quantitative analysis of their life habits could not be performed. A. philippiana was found in Mangrove Bay, Ferry Reach, using the method described by Obrochta \& Paisley (1970). L. radians could be detected offshore of Windsor Beach, north of North Rock in $17 \mathrm{~m}$ depth, and off the North East Breakers in $18 \mathrm{~m}$ depth in canyons.

Results from Harrington Sound were analyzed using the U-test of Mann and Whitney (95\% confidence) for the comparison of populations of species in different habitats. Thus the favorite biotopes of species were emphasized and compared to records of molluscan associations on the Bermuda platform and descriptions of their habitats (Gould 1968, Aurelia 1969, Waller 1973, Barnes \& v. Bodungen 1978, v. Bodungen et al. 1982).

The method described by Felbeck (1981) was used for testing the enzyme indicative of the presence of autotrophic bacteria in the gills, the characteristic enzyme of the Calvin-Benson cycle, ribulose-1,5-bisphosphate carboxylase. Gills were dissected from freshly collected animals and the activity assayed in the supernatant of a centrifuged (10 min, 27,000 g) homogenate.

\section{RESULTS}

\section{Occurrence and habitat of lucinid species in Bermuda}

Eight species of lucinids are known to live in Bermuda (Table 1), 5 of which we investigated; the other 3 species could not be found. The main collection site was in Harrington Sound where their habitat could be described by sediment analyses.

Grain size analyses of 2 transects in Harrington Sound are shown in Table 2 . The grain size shifts to smaller fractions with increasing depth. In Harrington Sound lucinid species range from shallow water (seagrass beds or close vicinity) down to the upper part of the Oculina zone $(10$ to $13 \mathrm{~m}$ ) (Fig. 1). In other lagoons, e.g. St. George's Harbour and Castle Harbour, lucinid species favor habitats with grain sizes similar to those found in Harrington Sound (Morris et al. 1977, v. Bodungen et al. 1982).

Codakia orbicularis predominantly occurs in seagrass beds ( $\mathrm{p}<0.05$, Fig. 1) (Thalassia testudium, Syringodium filiforme) in 5 to $12 \mathrm{~cm}$ depth, a few $\mathrm{cm}$ below the RPD-layer, although juveniles also settle in sandy and muddy sediments (Fig. 2). There, however, C. orbicularis does not reach the size possible in seagrass beds (no more than $16 \mathrm{~mm}$ compared to $>9 \mathrm{~cm}$ ).

Codakia costata and Ctena orbiculata are less abundant and show a very patchy distribution. Specimens of $1 \mathrm{~cm}$ diameter were found in the Oculina zone in about $4 \mathrm{~cm}$ depth. According to Aurelia (1969) they can be very abundant in Thalassia beds ( 26 ind $\mathrm{m}^{-2}$ ) but he did not separate the 2 species. Larval settlement is very low since the size classes of 1 to $2 \mathrm{~mm}$ were very rare throughout the year. $C$. orbiculata is not restricted to shallow water sediments but also favors muddy sediments (St. George's Harbour) or deeper water (Jackson 1973. Treece 1980). C. orbiculata has been described as a conspicuous infaunal element in Great Sound (v. Bodungen et al, 1982).

Table 1. Species of bivalves collected in Bermuda with locations (shown in Fig. 1) and range of distribution

\begin{tabular}{|lll|}
\hline \multicolumn{1}{|c}{ Species } & Locality & \multicolumn{1}{c|}{ Range of distribution } \\
\hline Linga pensylvanica (Linne 1758) & 1,2 & Cape Hatteras-West Indies \\
Parvilucina multilineata (Tuomey \& Holmes 1857) & $3,4,5,6,8,9$ & Cape Hatteras-West Indies-Brazil \\
Codakia orbicularis (Linne 1758) & $3,4,5,6,7,8$ & Florida-West Indies-Brazil \\
Codakia Costata (Orbigny 1842) & 5,8 & Cape Hatteras-West Indies-Brazil \\
Ctena orbiculata (Montagu 1808) & $3,5,8,9$ & Cape Hatteras-West Indies-Brazil \\
Ctena pectinella (Adams 1852) & $3,6,9$ & Florida-West Indies-Brazil \\
Lucina radians (Conrad 1841) & $10,11,12$ & Cape Hatteras-West Indies \\
Anodontia philippiana (Reeve 1850) & 4,8 & Cape Hatteras-Florida-Cuba \\
\hline
\end{tabular}


Table 2. Grain size distribution ( 1 exemplary sample per depth) of various surface sediments from 2 transects in Harrington Sound. Fractions expressed as \% of total dry weight. S: medium sand; SS: medium sand with fine sand and silt; $M+$ S: silt with fine sand; $M$ : silt; Sh: shell fragments; Oc: Oculina

\begin{tabular}{|c|c|c|c|c|c|c|c|}
\hline Depth $(\mathrm{m})$ & $>2000 \mu \mathrm{m}$ & $>500 \mu \mathrm{m}$ & $>200 \mu \mathrm{m}$ & $>63 \mu \mathrm{m}$ & $>20 \mu \mathrm{m}$ & $<20 \mu \mathrm{m}$ & Sediment \\
\hline \multicolumn{8}{|c|}{ Transect A } \\
\hline 10 & 30.6 & 11.4 & 9.2 & 27.2 & 17.4 & 2.2 & $\mathrm{M}+\mathrm{S}, \mathrm{Sh}, \mathrm{Oc}$ \\
\hline 11 & 4.7 & 15.9 & 13.7 & 20.6 & 40.9 & 3.6 & $M+S, S h, O c$ \\
\hline 16 & 1.5 & 5.1 & 4.8 & 25.2 & 58.1 & 4.9 & $\mathrm{M}, \mathrm{Sh}$ \\
\hline 19 & 0.5 & 4.8 & 5.9 & 15.1 & 65.7 & 7.9 & $\mathrm{M}, \mathrm{Sh}$ \\
\hline 22 & 0.4 & 0.2 & 0.9 & 10.2 & 76.8 & 10.7 & $M$ \\
\hline 24 & 0.7 & 0.3 & 0.9 & 5.7 & 78.6 & 11.6 & M \\
\hline \multicolumn{8}{|c|}{ Transect $B$} \\
\hline 2.5 & 6.2 & 37.1 & 50.0 & 5.6 & 0.9 & 0.2 & $\mathrm{~S}$ \\
\hline 7 & 13.3 & 31.3 & 39.7 & 7.8 & 5.1 & 2.9 & SS, Sh \\
\hline 12 & 9.8 & 6.8 & 7.9 & 25.9 & 48.1 & 3.8 & $\mathrm{M}+\mathrm{S}, \mathrm{Sh}, \mathrm{Oo}$ \\
\hline 15 & 1.4 & 2.9 & 3.7 & 22.0 & 55.9 & 4.5 & $\mathrm{M}, \mathrm{Sh}$ \\
\hline 16 & 17.2 & 4.9 & 3.9 & 10.1 & 58.0 & 5.0 & $\mathrm{M}, \mathrm{Sh}$ \\
\hline 18 & 14.3 & 8.9 & 7.9 & 10.2 & 53.2 & 4.7 & $\mathrm{M}, \mathrm{Sh}$ \\
\hline 20 & 3.5 & 5.0 & 10.2 & 12.0 & 63.6 & 4.7 & $\mathrm{M}, \mathrm{Sh}$ \\
\hline
\end{tabular}

Ctena pectinella prefers rather fine sandy sediments in protected shallow inshore bays (e.g. northeast of Smith's Island in St. George's Harbour and Tucker Town Cove in Castle Harbour) which are influenced by weak tidal currents.

Parvilucina multilineata is found predominantly in sheltered inshore bays with high sedimentation rates of fine particles due to reduced water movement (Fig. 3). It is very abundant and part of the dominant infauna. Harrington Sound which was investigated more closely has a variety of sediments ranging from very little silt content to silt with shell fragments (Table 1; Neumann 1965). The population density of $P$. multilineata ranges from 2 to 20 ind $0.1 \mathrm{~m}^{-2}$ in shallow sand, 3 to 46 ind $0.1 \mathrm{~m}^{-2}$ in sand with higher silt components, and 9 to 63 ind $0.1 \mathrm{~m}^{-2}$ in the upper part of the Oculina zone (Fig. 3), a belt ranging from 10 to $13 \mathrm{~m}$ depth with high sedimentation rates of fine
Fig. 1. Map of Bermuda with sampling locations: (1) Ireland Island, (2) Somerset Island, (3) Great Sound, (4) Hamilton Harbour, (5) Harrington Sound, (6) Castle Harbour, (7) Whalebone Bay, (8) Mangrove Bay, (9) St. George's Harbour, (10) North Rock, (11) Northeastern Breakers, (12) Southshore

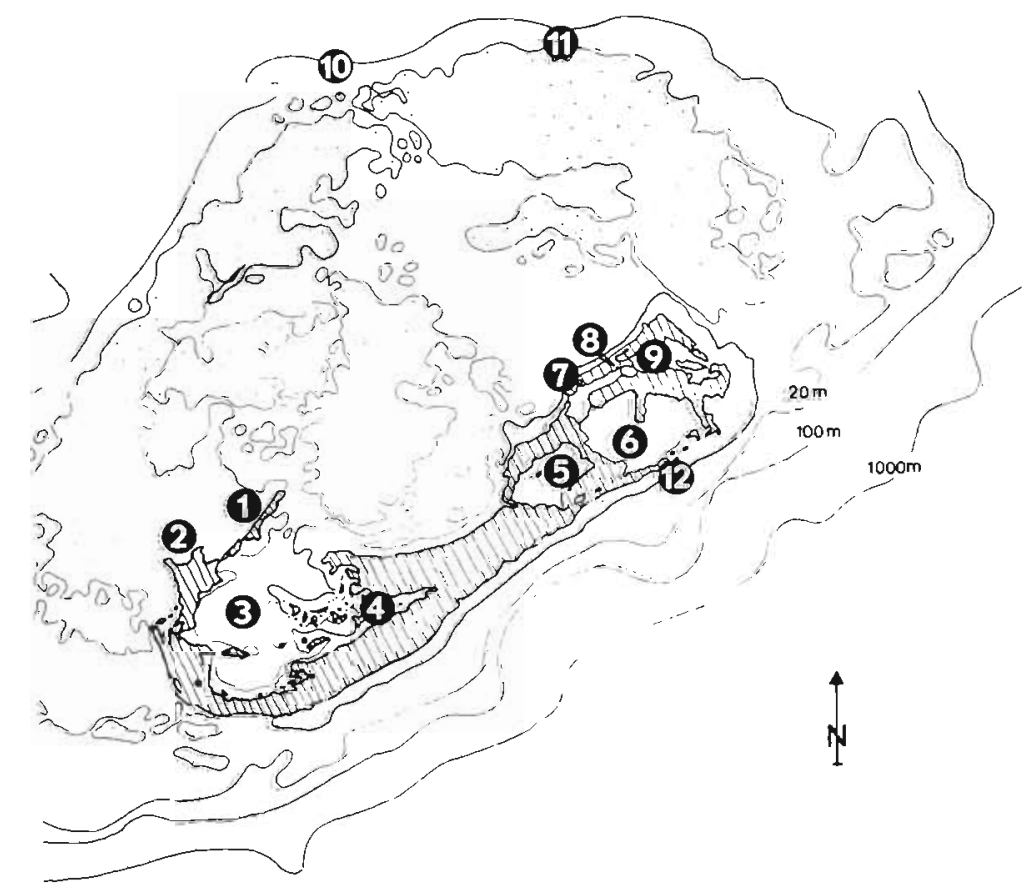




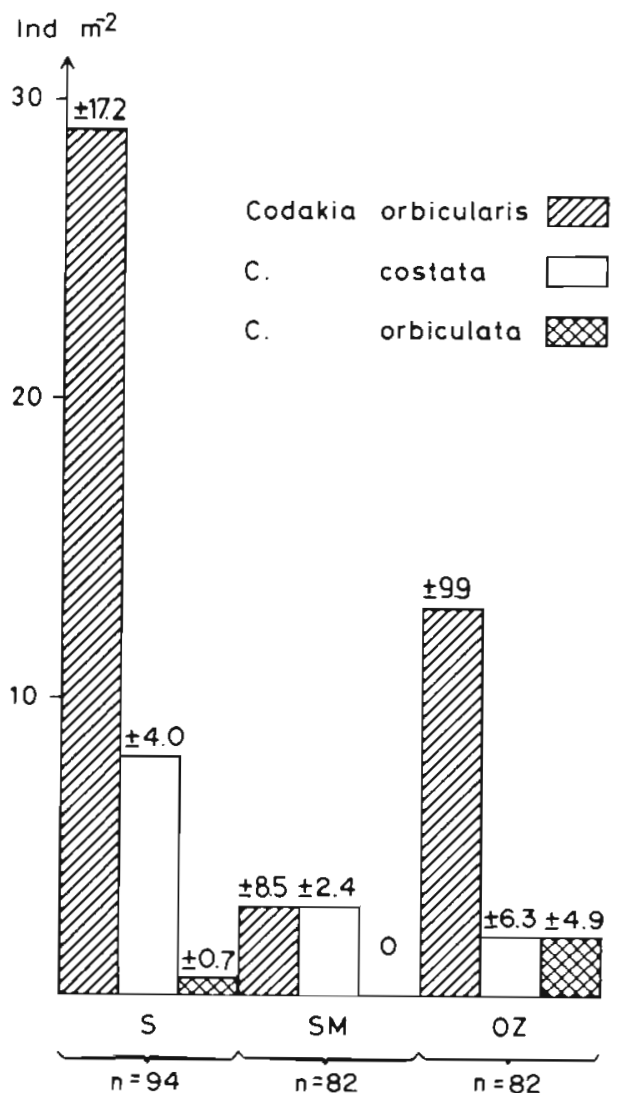

Fig. 2. Codakia orbicularis, C. costata, C. orbiculata. Abundance in various sediments. Means $\pm \mathrm{SD}$. S: shallow sand $(1$ to $3 \mathrm{~m}$ depth) ( $\mathrm{n}=94$ ); $\mathrm{SM}$ : sand with higher silt content (5 to $9 \mathrm{~m}$ depth) ( $\mathrm{n}=82)$; OZ: Oculina zone, shell and coral fragments, predominantly silt with a small fraction of fine sand

particles. From October to February P. multilineata was present in 43 to $71 \%$ of the samples taken at shallow sand stations while from March to September this ratio was between 86 and $100 \%$. Presence at other stations ranges between 83 and $100 \%$ throughout the year. The RPD-layer in this environment is at a few $\mathrm{mm}$ depth. Dwarf forms of 1 to $4 \mathrm{~mm}$ diameter lived down to $1 \mathrm{~cm}$ in the sediment, below the RPD-layer, and contained males ( $3.5 \mathrm{~mm}$ size) with ripe gonads and females (4.4 mm size) with fully developed eggs.

Lucina radians occurs in canyons along the reef fringe (North Rock, $15 \mathrm{~m}$ depth; N. E. Breakers, $17 \mathrm{~m}$ depth; sheltered canyons along South Shore). It is common in its habitat $\left(2\right.$ ind $\left.\mathrm{m}^{-2}\right)$ but the distribution pattern is patchy. Although still offering quite sheltered conditions the sediments inhabited by L. radians are more frequently disturbed by wave action or windinduced currents than inshore sediments. Sediment fractions are $\sim 10 \%$ debris (corals, shells) $>2 \mathrm{~mm}$, $\sim 50 \%$ very coarse to coarse sand with fine gravel 500 to $2,000 \mu \mathrm{m}, \sim 38 \%$ fine sand 125 to $500 \mu \mathrm{m}$, the rest contains silt plus organic components.

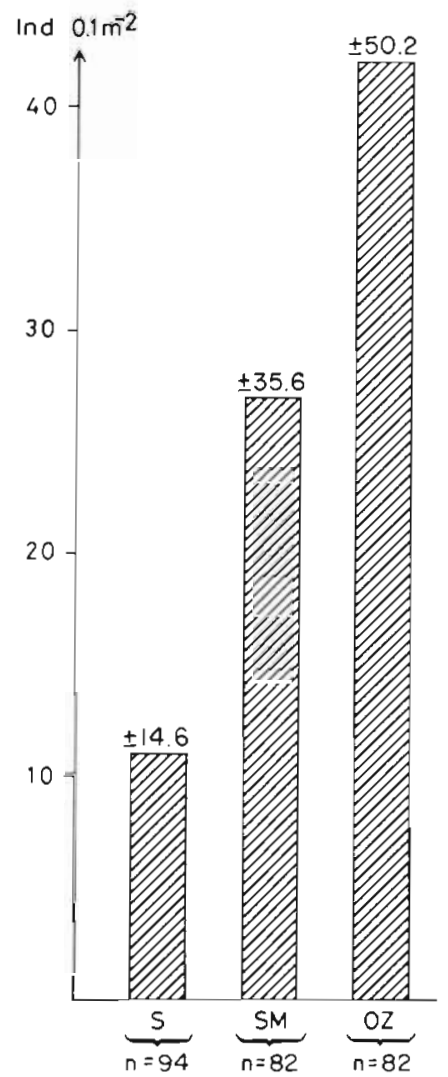

Fig. 3. Parvilucina multilineata. Abundance in various sediments. Means \pm SD. See Fig. 2 for explanation of abbreviations

Linga pensylvanica was only found at 2 sites (Ireland Island, Somerset Island) in shallow water Thalassia beds. It is considered to be very rare in Bermuda. Fossil records, however, are common in the vicinity of Mangrove Bay, Somerset Island and the southern part of Ireland Island (pers, obs. and collections).

Anodontia philippiana inhabits very sheltered bays often close to mangrove stands, e.g. Mangrove Bay, Ferry Reach (Obrochta \& Paisley 1970), and Hamilton Harbour (v. Bodungen et al. 1982). This species was widely distributed in inshore shallow waters in the past but possibly due to anthropogenic reduction of mangroves, populations are now very small and almost exclusively only fossil records are left (e.g. Millhouse Bay, Gibbet Island). Remainders of peat layers consisting of leaf and branch material were observed close to the fossils in these shallow bays. Specimens of $7 \mathrm{~cm}$ diameter were collected in Mangrove Bay, Ferry Reach, 60 to $70 \mathrm{~cm}$ deep in the sediment at the edge of a mangrove stand. The undisturbed sediments consist of silt to clay with thin intervening layers of fine sand. No juveniles were found. In Hamilton Harbour $A$. philippiana lives in muddy sediments in a passage

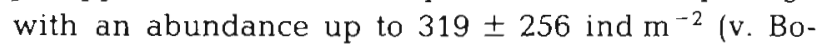
dungen et al. 1982 p. 77, Sta. 20). 
Table 3. Activities of ribulose-1,5-bisphosphate carboxylase in the gills of some bivalve species from Bermuda

\begin{tabular}{|lc|}
\hline \multicolumn{1}{|c|}{ Species } & $\begin{array}{c}\text { Activity } \\
\mu \mathrm{mol} \mathrm{min}^{-1} \text { ( } \mathrm{g} \text { fresh wt) }{ }^{-1}\end{array}$ \\
\hline Codakia orbiculata & 0.14 \\
Codakia costata & 0.32 \\
Anodontia philippiana & 0.1 \\
Lucina radians ${ }^{1}$ & 0.03 \\
Parvilucina multilineata ${ }^{1}$ & 0.03 \\
& \\
& \\
'Due to the small size of the animals no clean preparation \\
of gills was possible i.e. gill tissue was probably contami- \\
nated with mantle or foot tissue
\end{tabular}

Indication for autotrophic symbiotic bacteria in gills of Lucinidae

Gills were dissected from 5 bivalve species (listed in Table 3) and the activity of ribulose-1,5-bisphosphate carboxylase tested. The tests were positive indicating the presence of autotrophic bacteria. All gills were unusually thick, the color ranging from light brown to dark purple.

\section{DISCUSSION}

Five species of lucinid clams were shown to contain the enzyme ribulose-1,5-bisphosphate carboxylase in extracts of gill tissue. This enzyme is characteristic for the presence of the Calvin-Benson cycle of autotrophic $\mathrm{CO}_{2}$ fixation in microorganisms and plants, but not in animals. The presence of this enzyme in non-digestive (to avoid contamination by food or gut bacteria) and non-green (to avoid symbiotic algae or chloroplasts as source) animal tissues has been used in the past to indicate the existence of a symbiosis of autotrophic bacteria with an invertebrate host (Felbeck 1981, Felbeck et al. 1981). In all cases where a closer examination of the bacterial symbionts with electron microscopy was performed, its existence could be proven (Cavanaugh et al. 1981, Cavanaugh 1983, Felbeck 1983, Berg \& Alatalo 1984, Fischer \& Hand 1984, Giere et al. 1984, Giere 1985). It is therefore assumed that also in these newly described cases the enzyme is an indicator for bacteria in the gill cells. All the clams from Bermuda investigated in this paper live in a common environment which may be typical for lucinid bivalves containing bacterial symbionts. It is characterized by the availability of undisturbed sediments and input of organic material as has been summarized by Morris et al. (1977).

Lucinid clams containing bacterial symbionts are listed in Table 4. One group (Codakia orbicularis, Ctena orbiculata) prefers shallow inshore sediments in seagrass beds which are known to stabilize sediments, reduce water movements, and trap detritus and organic debris from the phytal zone of rocky shorelines (Fenchel 1970, Jackson 1972). This preference is also observed in the Caribbean (Stanley 1970, Jackson 1972, 1973, Turney \& Perkins 1972, Young \& Young

Table 4. List of lucinid clams proven or suspected to contain bacterial symbionts. Where no + is listed no information is available

\begin{tabular}{|c|c|c|c|}
\hline Subfamily and species & Dark gills & RuBPCase & Reference \\
\hline \multicolumn{4}{|l|}{ Lucininae } \\
\hline Linga (Lucina) pensylvanica & + & + & Berg \& Alatalo 1984 \\
\hline Parvilucina tenuisculpta & + & + & Felbeck et al. 1981 \\
\hline P. multilineata & + & + & $\cdot$ \\
\hline Codakia orbicularis & + & + & Berg \& Alatalo 1984 \\
\hline C. costatá & + & + & $\cdot$ \\
\hline Ctena orbiculata & + & + & $\cdot$ \\
\hline Ct. pectinella & + & & Jackson 1973 \\
\hline Lucina pectinata & + & & Read 1966, Jackson 1973 \\
\hline L. radians & + & + & 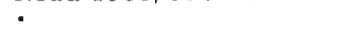 \\
\hline L. nassula & + & + & Berg \& Alatalo 1984 \\
\hline \multicolumn{4}{|l|}{ Myrteinae } \\
\hline Myrtea spinifera & + & & Schweimanns unpubl. \\
\hline Lucinoma annulata & + & + & Felbeck et al. 1981 \\
\hline \multicolumn{4}{|l|}{ Milthinae } \\
\hline Anodontia alba & + & & Jackson 1973 \\
\hline A. philippiana & + & + & $\cdot$ \\
\hline Pseudomiltha (Lucina) floridana & + & + & Fischer \& Hand 1984 \\
\hline - Species investigated in this study & & & \\
\hline
\end{tabular}


1982). The same habitat is preferred by Lucina pectinata and Linga pensylvanica (Stanley 1970, Young \& Young 1982). C. orbiculata dominates in sea water ponds (e.g. Walsingham Pond) with slow water exchange in 'muddy' sediments (Gould 1968). Parvilucina multilineata prefers biotopes with high organic sedimentation and resuspension. A similar distribution pattern is shown by the Pacific relative $P$. tenuisculpta, which favors either a biotope with coarse carbonate sediments and high organic content or a habitat influenced by highly organic sewage wastewater (Jones \& Thompson 1984).

Several adaptations to the habitat can be found in the lucinids on Bermuda and generally in other relatives, e.g. embryo protection by egg capsules (Miyazaki 1938, Blacknell \& Ansell 1974), and a reduction of the digestive tract which is expressed in loss of sorting areas and reduction of palps and ducts connecting digestive diverticula and stomach (Allen 1958). In the past, this has been interpreted as a simplification to enable species which live in an environment poor in suspended small food to consume large food particles such as decomposed organic material (Purchon 1960). The presence of symbiotic bacteria in the clam gills suggests another explanation for the reduced digestive tract, i.e. the animals do not need much, if any, particulate food, because all or part of their nutritional requirements are satisfied by using organic material released by the bacteria. In some other bivalves (Solemya reidi) or worms (e.g. all pogonophorans, the oligochaete Phallodrilus leukodermatus) containing bacterial symbionts the reduction of the digestive tract is complete, i.e. no digestive tract is formed (Reid 1980, Giere 1981, Ott et al. 1982). This finding suggests that these animals are able to survive entirely on the supply of reduced organic matter produced by the bacteria and uptake of dissolved organic material from the environment. It has been proposed that the symbiotic bacteria are supported by the presence of environmental hydrogen sulfide which they oxidize to gain energy for $\mathrm{CO}_{2}$ fixation (Felbeck et al. 1983). In the environment of the lucinid species in Bermuda conditions are comparable to the biotopes where other animals with reduced or absent guts are found. Sediments are rich in particulate and dissolved organic material (Erlenkeuser et al. 1981. Giere et al. 1982), and microbially produced sulfide is present in the immediate environment since all clams in Bermuda ascertained to have symbionts live beneath the RPD-layer (pers. obs.). Many other lucinid clams described live in similar environments to those on Bermuda (Stanley 1970, Moore \& Lopez 1972, Poore \& Rainer 1974, Tanaka \& Kikuchi 1979, Morton 1983). It has been shown that other animal/bacteria symbioses from sulfide rich habitats not only survive high sulfide concentrations, but also metabolize sulfide efficiently (Arp \& Childress 1983, Felbeck 1983, Powell \& Somero 1983). This ability has been attributed to either a sulfide detoxification system or the hemoglobin present in the gills of these animals (Doeller 1984). This dark color (ranging from light brown to deep purple), probably due to hemoglobin, has been found in gills of all bivalves containing bacteria. Unfortunately, only a few morphological descriptions of bivalves in the literature describe the color of the gill. Only Jackson (1973) mentions that Anodontia alba and Ctena pectinella from Jamaica have 'dark colored' gills with granules interpreted as respiratory pigments (Jackson 1973, Read 1966). The color of the gills is not characteristic for a given species but depends on the nutritional status of the clam. The gills of freshly collected clams are usually light brown and turn darker to dark purple during holding (Vetter 1985).

In summary, all lucinid species we have investigated contain symbiotic bacteria and live in environments with similar characteristics. In addition, all species have colored gills, which is a common feature of all bivalves with bacterial symbionts so far identified. Based on our results and information from the literature the conclusion is obvious that the presence of symbiotic bacteria may be a family characteristic of the Lucinidae. It could explain the reduced digestive tracts and the observation that lucinids are found in environments considered hostile to animals because of their high concentrations of sulfide.

Whether all members of the superfamily Lucinoidea form symbiotic associations still has to be evaluated. The Thyasiridae are certainly probable candidates to contain bacteria since they have so many characteristics in common with the Lucinidae, including dark colored gills with granules (Allen 1958, Jackson 1973), deep burrows in sediments (Stanley 1970), and egg capsules and lecitrophic development with short pelagic stage (Blacknell \& Ansell 1974).

How widely spread this phenomenon of a symbiosis between autotrophic bacteria and molluscs really is will be shown in the future. The number of associations known has increased dramatically since the original discovery in 1981 (Cavanaugh et al. 1981, Felbeck 1981). This occurrence of symbioses in pogonophorans, oligochaetes, and molluscs of the families Vesicomyidae, Solemyidae, and Lucinidae although polyphyletically acquired may have important evolutionary and systematical significance. An example could be the occurrence of endosymbionts in the Lucinidae which could provide another clue to possible relationships with other families, e.g. Thyasiridae.

Acknowledgements. M.S. was supported by a MontgomeryMoore Fellowship and participated at the BMFT-Projekt 
'Palaeoklima' (0710-52762-8). In addition, the studies were supported by grants from the NSF (OCE83-11259) and the National Geographic Society (2821-84) to H.F. Contribution No. 1046 of the Bermuda Biological Station.

\section{LITERATURE CITED}

Abbott, R. (1974). American Seashells. Second ed. Van Nostrand Reinhold, N.Y

Adshead, J. (1964). Iron content and pH characteristics of Bermuda carbonate muds. In: Chave, K. E. (ed.) Report on advanced sciences seminar in marine organism-sediment interrelationships. Berm. Biol. Stn 1964: 1-5

Allen, J. (1958). On the basic form and adaptations to habitat in the Lucinacea (Eulamellibranchia). Phil. Trans. R. Soc. B 684: 421-484

Aurelia, M. (1969). The habitats of some subtidal pelecypods in Harrington Sound, Bermuda. In: Ginsburg, R. N., Stevens, S. M. (ed.) Seminar on organism-sediment interrelationship. Berm. Biol. Stn Spec. Publ. 6: 39-52

Arp, A., Childress, J. (1983). Sulfide binding by the blood of the hydrothermal vent tube worm, Riftia pachyptila. Science 219: 295-297

Barnes, J., v. Bodungen, B. (1978). The Bermuda marine environment, Vol. II. Berm. Biol. Stn Spec. Publ. 17: 1-190

Berg, C., Alatalo, P. (1984). Potential of chemosynthesis in molluscan mariculture. In: Morse, D. E., Chew, K. K., Mann, R. (ed.) Recent innovations in cultivation of pacific molluscs. Elsevier, Amsterdam, p. 165-179

Blacknell, W., Ansell, A. (1974). The direct development of the bivalve Thyasira gouldi (Philippi). Thalassia jugosl. 10: $23-43$

v. Bodungen, B., Jickells, T., Smith, S., Ward, J., Hillier, G. (1982). The Bermuda marine environment, Vol. III. Berm. Biol. Stn Spec. Publ. 18: 1-123

Britton, J. (1972). Two new species and a new subgenus of Lucinidae (mollusca), with notes on certain aspects of lucinid phylogeny. Smithson. Contr. Zool. 129: 1-19

Cavanaugh, C., Gardiner, S., Jones, M., Jannasch, H., Waterbury, J. (1981). Prokaryotic cells in the hydrothermal vent tube worm Riftia pachyptila Jones: Possible chemoautotrophic symbionts. Science 213: 340-342

Cavanaugh, C. (1983). Symbiotic chemoautotrophic bacteria in marine invertebrates from sulphide-rich habitats. Nature, Lond. 302: 58-61

Erlenkeuser, H., Dawson, R., Fuetterer, D., Heinrich, H., Liebezeit, G., Meischner, D., Mueller, P., Wefer, G. (1981). Environmental changes during the last 9000 years as reflected in a sediment core from Harrington Sound, Bermuda. In: Wefer, G. R., Dawson, R., Hempel, G. (ed.) The Harrington Sound Project, Kiel University. Berm. Biol. Stn Spec. Publ. 19: 1-94

Doeller, J. E. (1984). A hypothesis for the metabolic behavior of Solemya velum, a gutless bivalve. Am Zool. 24: 57 A

Felbeck, H. (1981). Chemoautotrophic potential of the hydrothermal vent tube worm Riftia pachyptila Jones (Vestimentifera). Science 213: 336-338

Felbeck, H. (1983). Sulfide oxidation and carbon fixation by the gutless clam Solemya reidi: An animal-bacteria symbiosis. J. comp. Physiol. 152: 3-11

Felbeck, H., Childress, J., Somero, G. (1981). Calvin-Benson cycle and sulphide oxidation enzymes in animals from sulphide-rich habitats. Nature, Lond. 293: 291-293

Felbeck, H., Childress, J., Somero, G. (1983). Biochemical interactions between molluscs and their algal and bacterial symbionts. In: Hochachka, P. W. (ed.) The mollusca, Vol. 2. Academic Press, New York, p. 331-358
Fenchel, T (1970). Studies on the decomposition of organic detritus derived from turtle grass, Thalassia testudinum. Limnol. Oceanogr 15: 14-20

Fisher, M., Hand, S. (1984). Chemoautotrophic symbionts in the bivalve Lucina floridana from Seagrass beds. Biol. Bull mar biol. Lab., Woods Hole 165: 167-181

Giere, O. (1981). The gutless marine oligochaete Phallodrilus leukodermatus. Structural studies on an aberrant tubificid associated with bacteria. Mar. Ecol. Prog. Ser. 5: 353-357

Giere, O., Liebezeit, G., Dawson, R. (1982). Habitat conditions and distribution patterns of the gutless oligochaete Phallodrilus leukodermatus. Mar. Ecol. Prog. Ser. 8: 291-299

Giere, O., Felbeck, H., Dawson, R., Liebezeit, G. (1984). The gutless oligochaete Phallodrilus leukodermatus Giere, a tubificid of structural, ecological, and physiological relevance. Hydrobiologia 115: 83-89

Giere, O. (1985). Structure and position of bacterial endosymbionts in the gill filaments of Lucinidae from Bermuda (Mollusca, Bivalvia). Zoomorph. (in press)

Gould, S. (1968). The molluscan fauna of an unusual pond, a natural experiment in form and composition. Breviora 308 : $1-13$

Jackson, J. (1972). The ecology of the molluscs of Thalassia communities, Jamaica, West Indies. II. Molluscan population variability along an environmental stress gradient. Mar. Biol. 14: 304-337

Jackson, J. (1973). The ecology of Thalassia communities, Jamaica, West Indies. VI. Distribution, environmental physiology, and ecology of common shallow water species. Bull. mar. sci. 23: 313-350

Jones, G., Thompson, B. (1984). The ecology of Parvilucina tenuisculpta (Carpenter, 1864) (Bivalvia, Lucinidae) on the southern California borderland. Veliger 26: 188-198

Miyazaki, J. (1938). On the incubatory habitats and shelled larvae of bivalves. II. Bot. Zool. Tokyo 6/7: 1213-1218

Moore, H. B., Lopez, N. N. (1972). A contribution to the ecology of the lamellibranch Anodontia alba. Bull. mar. sci. 22: 381-390

Morris, B., Barnes, J., Brown, I., Markham, J. (1977). The Bermuda marine environment: a report of the Bermuda inshore waters investigation 1976-1977. Berm. Biol. Stn Res. Spec. Publ. 15

Morton, B. (1983). Mangrove bivalves. In: Wilbur, K. W. (ed.) The mollusca, Vol. 2. Academic Press, New York, p. $77-138$

Neumann, C. (1965). Process of recent carbonate sedimentation in Harrington Sound, Bermuda. Bull. mar. sci. 15: $987-1035$

Obrochta, J. A., Paisley, D. C. (1970). Observations on the ecology of the pelecypod Anodontia schrammi in Bermuda. Berm. Biol. Stn Spec. Publ. 7: 7-12

Ott, J., Rieger, G., Rieger, R., Enders, F. (1982). New mouthless interstitial worms from the sulfide system: Symbiosis with prokaryotes. P.S.Z.I. Mar. Ecol. 3: 313-333

Poore, G., Rainer, S. (1974). Distribution and abundance of softbottom molluscs in Port Phillip Bay, Victoria, Australia. Aust. J. mar. Freshwat. Res. 25: 371-411

Powell, M., Somero, G. (1983). Blood components prevent sulfide poisoning of respiration of the hydrothermal vent tube worm, Riftia pachyptila. Science 219: 297-299

Purchon, R. (1960). The stomach in the Eulamellibranchia; stomach types IV and V. Proc. zool. Soc. Lond. 135: $431-489$

Read, K. (1966). The hemoglobin and myoglobin. In: Wilbur, K. W., Yonge, M. (ed.) Physiology of mollusca, Vol. 2. Academic Press, New York, p. 209-232

Reid, R. (1980). Aspects of the biology of a gutless species of 
Solemya (Bivalvia: Protobranchia). Can. J. Zool. 58: 386-393

Southward, A., Southward, E., Dando, P., Rau, G., Felbeck, H., Fluegel, $H$. (1981). Bacterial symbionts and low ${ }^{13} \mathrm{C} /{ }^{12} \mathrm{C}$ ratios in tissues of Pogonophora indicate unusual nutrition and metabolism. Nature, Lond. 293: 616-617

Southward, E. (1982). Bacterial symbionts in Pogonophora. J. mar. biol. Ass. U.K. 62: 889-906

Stanley, S. (1970). Relation of shell form to live habits of the bivalvia (Mollusca). Geol Soc. Am., Inc. Mem. 125: 1-293

Tanaka, M., Kikuchi, T. (1979). Ecological studies on benthic macrofauna in Tomoe Cove, Amakusa, Japan. 3. Life history and population fluctuation of major molluscs. Publ. Amakusa Mar. Biol. Lab., Kyushu Univ. 5: 79-115

Treece, G. (1980). Bathymetric records of marine shelled mollusca from the northeastern shelf and upper slope of Yucatan, Mexico. Bull. mar. sci. 30: 552-570

Tumey, W. J., Perkins, J. (1972). Molluscan distribution in Florida Bay. The comparative sedimentology laboratory, Division of marine geology and geophysics, University of Miami. Sedimenta spec. publ. III; 1-37

Vetter, R. (1985). Elemental sulfur in the gills of three species of clams containing chemoautotrophic symbiotic bacteria: a possible inorganic energy storage compound. Mar. Biol., in press

Waller, T. (1973). The habits and habitats of some bermudian marine molluscs. Nautilus 87: 31-52

Young, D., Young, M. (1982). Macrobenthic invertebrates in bare sand and seagrass (Thalassia testudinum) at Carrie Bow Cay, Belize. Smithson. Contr. mar. Sci. 12: 115-126

This paper was presented by Professor N. D. Holland; it was accepted for printing on April 29, 1985 